\title{
Isostatic uplift in the late Weichselian Barents Sea: implications for ice-sheet growth
}

\author{
M. J. Siegert \\ Centre for Glaciology, Institute of Earth Studies, University of Wales, Aberystwyth, Dyfed S123 3DB, Wales \\ W. FJELDSKAAR \\ Rogaland Research, P.O. Box 2503, 4004 Stavanger, Norway
}

\begin{abstract}
Results from a recent time-dependent ice-sheet modelling study of the late Weichselian Svalbard-Barents Sea ice sheet suggest that, under environmental conditions representative of those during the late Weichselian, ice derived solely from Svalbard may have occupied only the relatively shallow $(<300 \mathrm{~m}$ water depth) northwestern Barents Sea, with other deeper regions remaining free of grounded ice (Siegert and Dowdeswell, 1995a). However, late Weichselian geological information from the $400 \mathrm{~m}$ deep Bjørnøyrenna (southern Barents Sea) indicates that grounded ice was present in an area modelled by Siegert and Dowdeswell (1995a) as free of ice (e.g. Laberg and Vorren, in press a). Isostatic uplift of the central Barents Sea may have reduced the relative sea level and hence provided a mechanism by which grounded ice could have migrated from relatively shallow regions of the Barents Sea into, previous to uplift, deeper water. We have used an isostatic Earth model to determine the geometry of an isostatic forebulge within the late Weichselian Barents Sea, caused by ice loads over Svalbard, Franz Josef Land, Novaya Zemlya and Fennoscandia. These data were then used as input to a time-dependent glaciological model, in order to predict further information about the magnitude of bedrock uplift required to allow grounded ice to flow from Svalbard into the central and southern Barents Sea. Our experiments suggest that grounded ice, originating from Svalbard, is able to form over Sentralbanken, providing that at least $60 \mathrm{~m}$ of uplift is achieved in the central Barents Sea. Grounded ice within Bjornoyrenna was only predicted when the amplitude of the local forebulge exceeded $250 \mathrm{~m}$.
\end{abstract}

\section{INTRODUCTION}

Several previous reconstructions of the last Svalbard Barents Sea ice sheet have indicated complete grounded coverage of the Barents Shelf by an ice sheet up to $2.5 \mathrm{~km}$ thick (e.g. Denton and Hughes, 1981; Grosswald, 1988; Lindstrom and MacAyeal, 1989). However, a number of recent geological investigations on Svalbard and the Barents Shelf region, concerning both the timing of icesheet build-up and the maximum ice-sheet dimensions, have indicated that this scenario may be unlikely for the late Weichselian glaciation (e.g. Mangerud and Svendsen, 1992; Elverhoi and others, 1993; Hebbeln and others, 1994).

Ice-sheet growth within the late Weichselian Barents Sea began relatively late in the glacial, at approximately 25000 years ago. The Svalbard-Barents Sea ice sheet may have, therefore, had less than 8000 years to grow to its maximum dimensions before the onset of deglaciation (Hebbeln and others, 1994). During this time, seasonal sea-ice-free conditions existed in the eastern margin of the Norwegian-Greenland Sea and may have allowed relatively high rates of iceberg calving at the western grounded margin of the Svalbard-Barents Sea ice sheet
(Hebbeln and others, 1994). Recent glaciological modelling studies have indicated that a grounded ice sheet, covering the entire Barents Shelf with an ice thickness of up to $2.5 \mathrm{~km}$, with iceberg calving on the western Barents Shelf, would have required a period of growth in excess of 15000 years (Siegert and Dowdeswell, in press). Moreover, numerical modelling has also predicted that, if iceberg calving occurred within the central regions of the Barents Sea, the maximum extent of the ice sheet covered only the relatively shallow regions around Svalbard and the northwestern Barents Sea (Figs 1 and 2). In this latter glacial reconstruction, the ice sheet was separated from ice masses in both Fennoscandia and the Kara Sea and no grounded ice was formed over the deeper regions of the Barents Sea such as Bjornøyrenna or the Central Deep (Fig. 1).

Glacigenic sediments and moraine ridges within Bjornoyrenna indicate that this trough has been glaciated (e.g. Sxttem and others, 1992). Bjornoyrenna is the deepest trough within the western Barents Sea and has an extensive glacigenic sedimentary fan at its mouth (Fig. 1). Radiocarbon dating of the upper region of the Bjornoyrenna fan indicates that this region experienced high rates of sediment deposition during the late Weichselian 


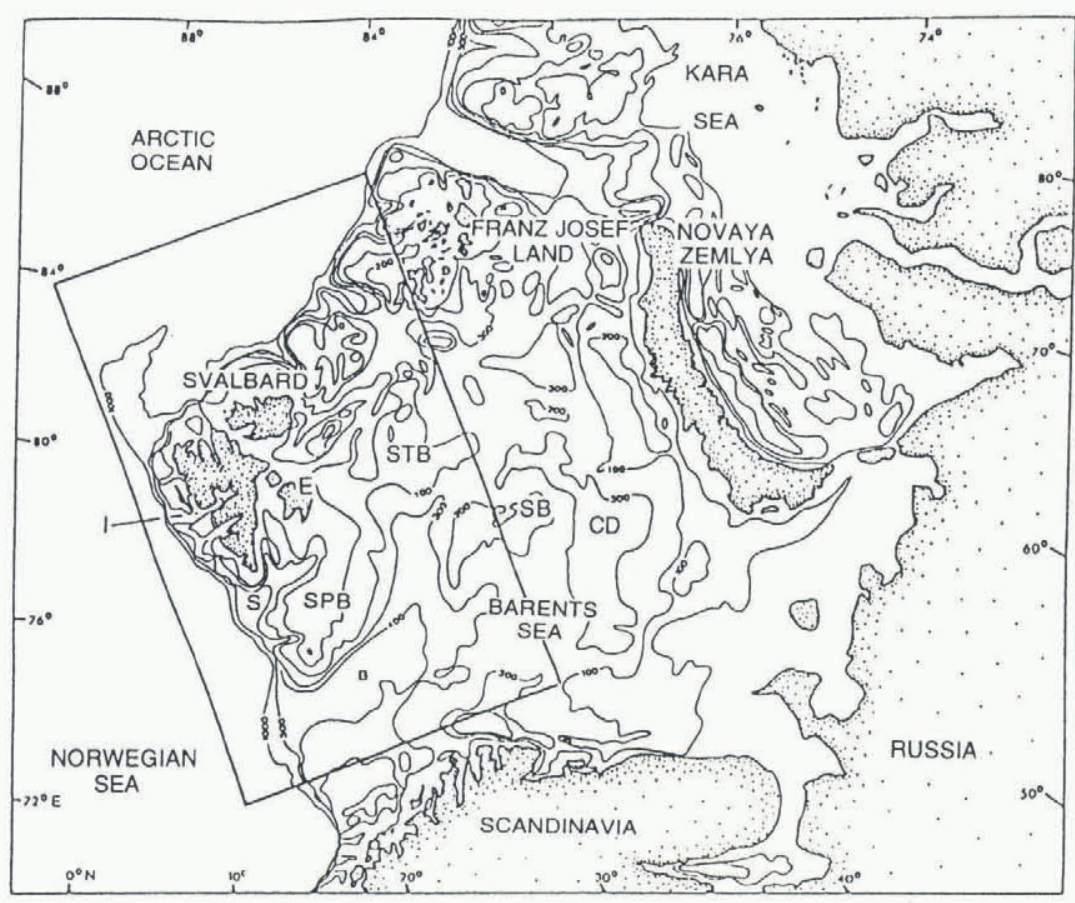

Fig. 1. The location and present bathymetry of the Barents Sea. E, Edgeoya; B, Bjornoyrenna; S, Storfjordrenna; I, Isfjorden; SB, Sentralbanken; STB, Storbanken; SPB, Spitsbergenbanken; CD, Central Deep. The box denotes the position of the two-dimensional numerical grid used in the numerical ice-sheet model results illustrated in Figure 2.

glaciation (i.e. $124 \mathrm{~cm}^{1000 \text { years }}{ }^{-1}$, (Laberg and Vorren, in pressa)), which caused large-scale debris flows on to the deeper regions of the fan Laberg and Vorren, in press b). The geometry of Bjornøyrenna is likely to derive from the abrasive action of an ice stream throughout a number of glaciations, which can be individually identified within the fan sequence (e.g. Vorren and others, 1988; Sættem and others, 1992). If the Barents Sea was totally covered by grounded ice, it is highly probable that grounded ice would have flowed from the central Barents Sea through Bjornoyrenna to the continental


Fig. 2. (a) Ice thickness and (b) surface elevation for the numerical ice-sheet reconstruction of Siegert and Dowdeswell (1995b). Contours at every $200 \mathrm{~m}$. The position of horizontally one-dimensional transect lines are indicated. shelf break where sub-marine pro-glacial sedimentation would have occurred. Within the mouth of Bjornoyrenna, a series of moraines which lie across the trough i.e. perpendicular to the estimated direction of ice flow) has been detected seismically (Elverhoi and Solheim, 1983; Vorren and Kristoffersen, 1986). The Bjornoyrenna moraines have been interpreted by some to be of late Weichselian age, since they are covered by only a thin layer of fine-grained Holocene sediments. Thus, at around the Last Glacial Maximum (LGM) between 22000 and 18000 years ago, the grounded-ice margin of the Svalbard-Barents Sea ice sheet migrated from the relatively shallow (less than $300 \mathrm{~m}$ water depth) banks of the northwestern Barents Sea into Bjornoyrenna (Elverhoi and others, 1993). However, the cause of the ice-sheet advance from the relatively stable margin in the northwestern Barents Shelf into deeper regions of the Barents Sea at between 22000 and 18000 years ago has yet to be determined.

Siegert and Dowdeswell (1995a) proposed that, if Bjornoyrenna was covered by grounded ice during the late Weichselian, then a mechanism, external to their model of the Svalbard-Barents Sea ice-sheet system, which would have allowed grounded ice to have formed rapidly within the deepest regions of the Barents Sea, may have been in operation during the last glacial. Such processes include (i) grounded-ice migration from nearby ice sheets in Scandinavia and the Kara Sea, (ii) the processes of sea-ice-induced ice-shelf thickening and (iii) isostatic uplift of the central Barents Sea floor due to a forebulge caused by the ice loading of the northwestern Barents Sea, Fennoscandia and the Kara Sea. This paper aims to assess the likelihood of grounded-ice extension beyond the limits of the northwestern Barents Sea, caused solely by the process of isostatic uplift within the central regions of the Barents Sea. 


\section{MODELLING PROCEDURE}

The ice-sheet model used in this study is centred around the continuity equation for ice (Mahaffy, 1976) where the time-dependent change in ice thickness is associated with the specific net mass budget of an ice cell. Ice temperature is calculated from the steady-state method of Robin (1955). However, this solution of the ice-temperature field is only applicable close to the ice divide, since it assumes constant vertical strain rate, and does not account for horizontal heat advection. Thus, ice-temperature calculations far from the modelled ice divide may be too high. This problem is addressed simply, by not allowing the mean ice temperature of a cell to exceed $-5^{\circ} \mathrm{C}$ (a temperature often used in isothermal models to determine the flow-law parameter). Grounded-ice velocity is calculated as the sum of depth-averaged ice deformation (Paterson, 1994) and basal sliding (Budd and others, 1984). The basal-sliding velocity is related to the effective pressure and not the temperature of basal ice. Thus, the model is relatively stable to changes in the maximum temperature allowed in an ice cell, within the thermal regime mentioned above. Bedrock elevation change, caused by variation of ice thickness, is determined by an asthenospheric diffusion equation Oerlemans and Van der Veen, 1984). Further details of the model are discussed in Siegert and Dowdeswell (1995a).

Siegert and Dowdeswell (1995b) produced an icesheet reconstruction by employing the model described above, forced by environmental conditions representative of those of the late Weichselian, run until steady-state was achieved with respect to both mass balance and ice-sheet dimensions. The corresponding equilibrium ice sheet covered only the northwestern Barents Sea (Fig. 2). The position of the calculated grounded-ice margin corresponds with the location of glacigenic sea-floor structures (Elverhøi and Solheim, 1983). No grounded ice was calculated over Sentralbanken or Bjørnøyrenna (Fig. 2).

This study uses a similar glaciological model (in horizontally one-dimensional, transect form) and the same environmental forcing conditions, held constant at full glacial values, as in the horizontally two-dimensional numerical studies of Siegert and Dowdeswell (1995b).

An initial experiment calculated steady-state ice sheet results across two transects within the Barents Sea (Fig. 2 ). The resulting ice sheet indicates, after comparison with the original ice-sheet reconstruction of Siegert and Dowdeswell (1995a), any modification in the originally calculated dimensions due solely to the one-dimensional form of the model.

Results from an isostatic model of the Barents Shelf are then discussed in order to identify the geometry of the forebulge that may have existed within the late Weichselian Barents Shelf.

The ice-sheet model was then run across both transects again within a series of experiments in which regions of the Barents Sea floor were uplifted to account for the isostatic influence of the Fennoscandian and Kara Sea ice sheets on the Barents Shelf morphology. The results indicate how ice growth beyond the limits proposed by Siegert and Dowdeswell (1995a) is possible if an isostatic forebulge within the central Barents Sea existed during the late Weichselian glaciation. The ice-sheet model was then run in a number of sensitivity exercises to determine the ice-sheet response to variations in the magnitude of the imposed isostatic uplift. Note that the ice-sheet model's isostatic treatment is still active after the uplift, representing a forebulge. Consequently, grounded ice will act to depress the forebulge when located over it.

The ice-sheet results presented in this paper are calculated over two transects: one positioned from Svalbard to Sentralbanken (involving $50,20 \mathrm{~km}$ wide cells) and another, 70 cell transect located from Svalbard, over Spitsbergenbanken to Bjørnøyrenna (Fig. 2).

\section{ENVIRONMENTAL FORGING AND MODEL BOUNDARY CONDITIONS}

The model requires inputs of accumulation rates, mean annual sea-level air temperature, rates of iceberg calving and sea-level depression. An equilibrium approach to modelling is adopted, requiring that forcing data are held constant at their full glacial values, and the model run until steady-state is achieved with respect to ice-sheet size.

It is assumed that, prior to glaciation, the bedrock elevation of the Svalbard-Barents Sea region was similar to that of today, such that the present bedrock elevation could be used to define initial conditions in the model (Siegert and Dowdeswell, 1995a, b). Justification for this assumption is based on sedimentary evidence from central Svalbard that indicates interstadial conditions between 50000 and 30000 years ago (Mangerud and Svendsen, 1992), during which glaciers on Svalbard were no larger than at present.

During the last glaciation, seasonal sea-ice-free conditions existed in the Norwegian-Greenland Sea which acted to supply the Barents Sea with relatively large rates of precipitation (e.g. Hebbeln and others, 1994). The modern altitude-precipitation relationship, defined as Polar Mix by Pelto and others (1990), describes the modern mean accumulation of ice on glaciers in the High Arctic and, in particular, Svalbard. The rates of accumulation at the LGM are estimated by adjusting the Pelto and others' relation to account for a LGM sealevel air temperature of $-15^{\circ} \mathrm{C}$ (Manabe and Bryan, $1985)$ through an adiabatic altitude-related temperaturelapse rate (Fortuin and Oerlemans, 1990).

The sea-level depression for the glaciological model is set at $120 \mathrm{~m}$ below modern sea level, the maximum value that has been measured on several raised terraces of lowlatitude coral reefs (Fairbanks, 1989).

Iceberg calving is introduced to the marine margin of the modelled ice sheet in the form of a depth-related function (Pelto and Warren, 1991). A detailed discussion of the forcing inputs to the numerical model can be found in Siegert and Dowdeswell (1995b).

\section{MODEL RESULTS WITHOUT AN ISOSTATIC FOREBULGE}

For the cases of both transects where no isostatic forebulge was accounted for, the model reconstruction formed an initial ice sheet by accumulating ice over Svalbard after about 5000 years of model time which, during the 


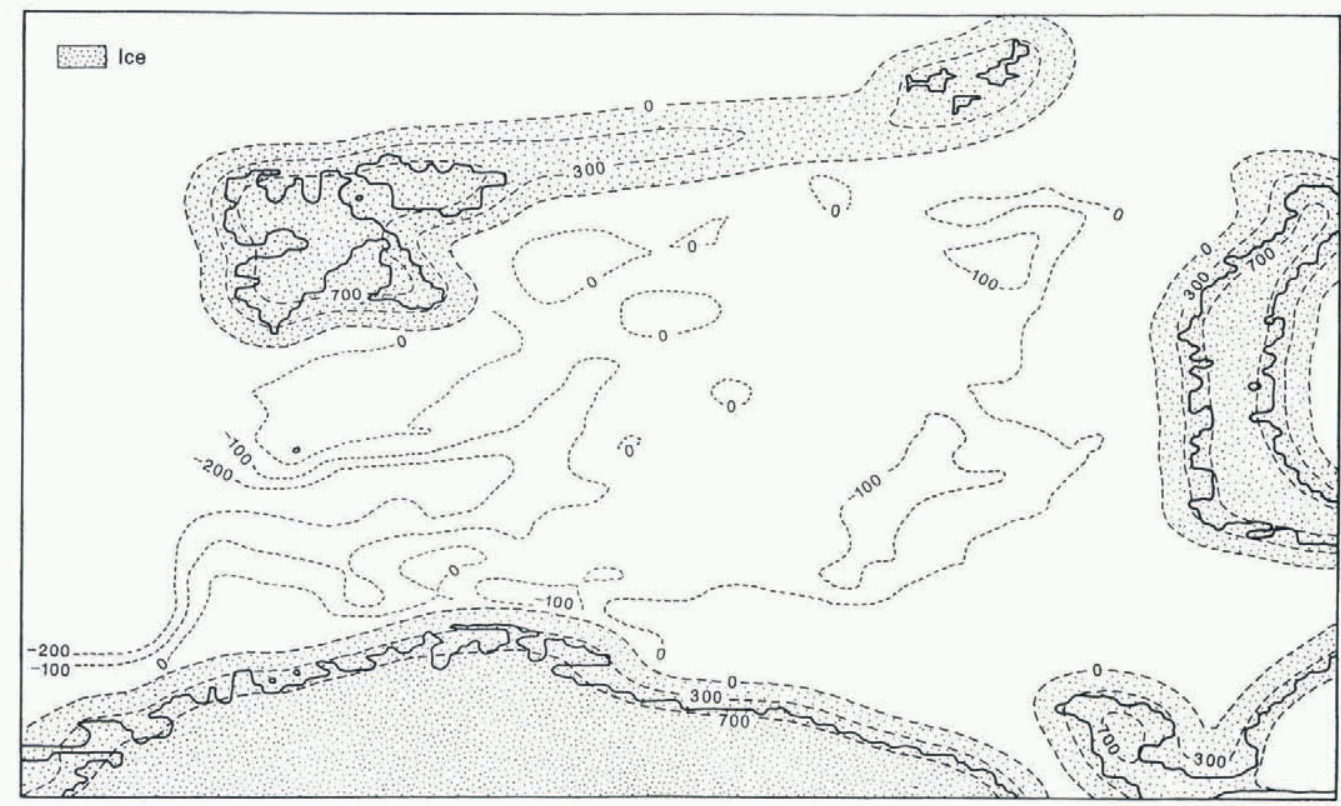

Fig. 3. Isostatic model results, illustrating the bathymetry of the Barents Shelf after an ice load, limited to the northern Barents Sea, Novaya Zemlya and Fennoscandia reaches an isostatic equilibrium with the Earth. Note that central regions of the Barents Sea are aerially exposed, implying a forebulge of between 50-100 m.

succeeding 5000 years, spread over the neighbouring shallow sea on to Spitsbergenbanken. By 12000 years of model time, the ice sheet had grown to its maximum steady-state size. For transect I over Sentralbanken, the ice sheet had a maximum thickness of about $1510 \mathrm{~m}$, whilst in transect II over Bjornøyrenna the maximum ice thickness was $1580 \mathrm{~m}$. In both transects, the location of maximum ice thickness was over the shallow waters within Storfjorden. Importantly, the dimensions and extent of the ice sheet calculated with the one-dimensional transect model is very similar to that calculated within a pseudo three-dimensional model of the ice sheet in that grounded-ice growth was limited to the northwestern Barents Sea (Fig. 2).

\section{ISOSTATIC MODEL OF UPLIFT IN THE BARENTS SEA}

The response of the Barents Shelf lithosphere to build-up of glaciers in the northwest Barents Sea, Novaya Zemlya and Fennoscandia was determined by an Earth model representing a non-spherical viscous fluid mantle, in which the viscosity is allowed to vary with depth, overlain by a uniformly thick elastic lithosphere. The method used, which accounts for both isostasy and eustasy, has been described in detail by Cathles (1975) and Fjeldskaar and Cathles (1991).

Eustasy can be regarded as vertical changes of sea level and may be of three types: (1) glacial eustasy, controlled by variation of the ocean-water volume, (2) tectono eustasy, controlled by variation of the oceanbasin volume and (3) geoidal eustasy. Geoidal eustasy, representing changes of the ocean-water distribution due to variations in the Earth's gravity field, is not considered. The eustatic change is here assumed to be $140 \mathrm{~m}$ between 20000 years ago and the present day. We note that the sea-level depression used in the Earth model is $20 \mathrm{~m}$ lower than in the glaciological model. However, Earth-model senstivity tests on the forebulge response to sea-level depression, not presented in this paper, indicate that the bathymetry predicted by the Earth model for $140 \mathrm{~m}$ of sea-level fall can be replicated, with slight modifications to the ice thickness and flexural rigidity inputs, when the sea-level depression is $120 \mathrm{~m}$.

Hydro-isostasy (the movement of the ocean bottom caused by the sea-level change) is calculated separately by the Earth model. The land-ocean distribution during the deglaciation is assumed to be similar to that at present.

The theoretical movements of the ocean floor in the Barents Sea during the period in which ice-sheet growth occurred, assuming isostatic equilibrium, was based on a lithosphere rigidity of $10^{23} \mathrm{Nm}$ and an effective elastic thickness of the lithosphere of $20 \mathrm{~km}$.

A forebulge within the central Barents Sea with an amplitude of over $50 \mathrm{~m}$ was calculated after the ice distribution, limited to Svalbard and the surrounding shallow sea, Novaya Zemlya and Fennoscandia, was used as input (Fig. 3). In addition, the amplitude of the forebulge within the bathymetric trough of Bjornoyrenna (Fig. 1) was predicted by the Earth model to be around $50 \mathrm{~m}$ (Fig. 3). When sea-level reduction is accounted for in the model, several regions of the central Barents Shelf become aerially exposed (e.g. Sentralbanken). The maximum uplift is located no closer than $100 \mathrm{~km}$ from the ice margin and has a parabolic form with zero amplitude at the ice margin (Fig. 3). Such uplift and the effect it may have had on ice-sheet growth within the Barents Sea, is now discussed.

The forebulge information from the isostatic model is input to the glaciological model slightly differently across each transect. In transect I, over Sentralbanken, the Fennoscandian ice margin is located far outside the transect. The region of maximum uplift is subsequently 

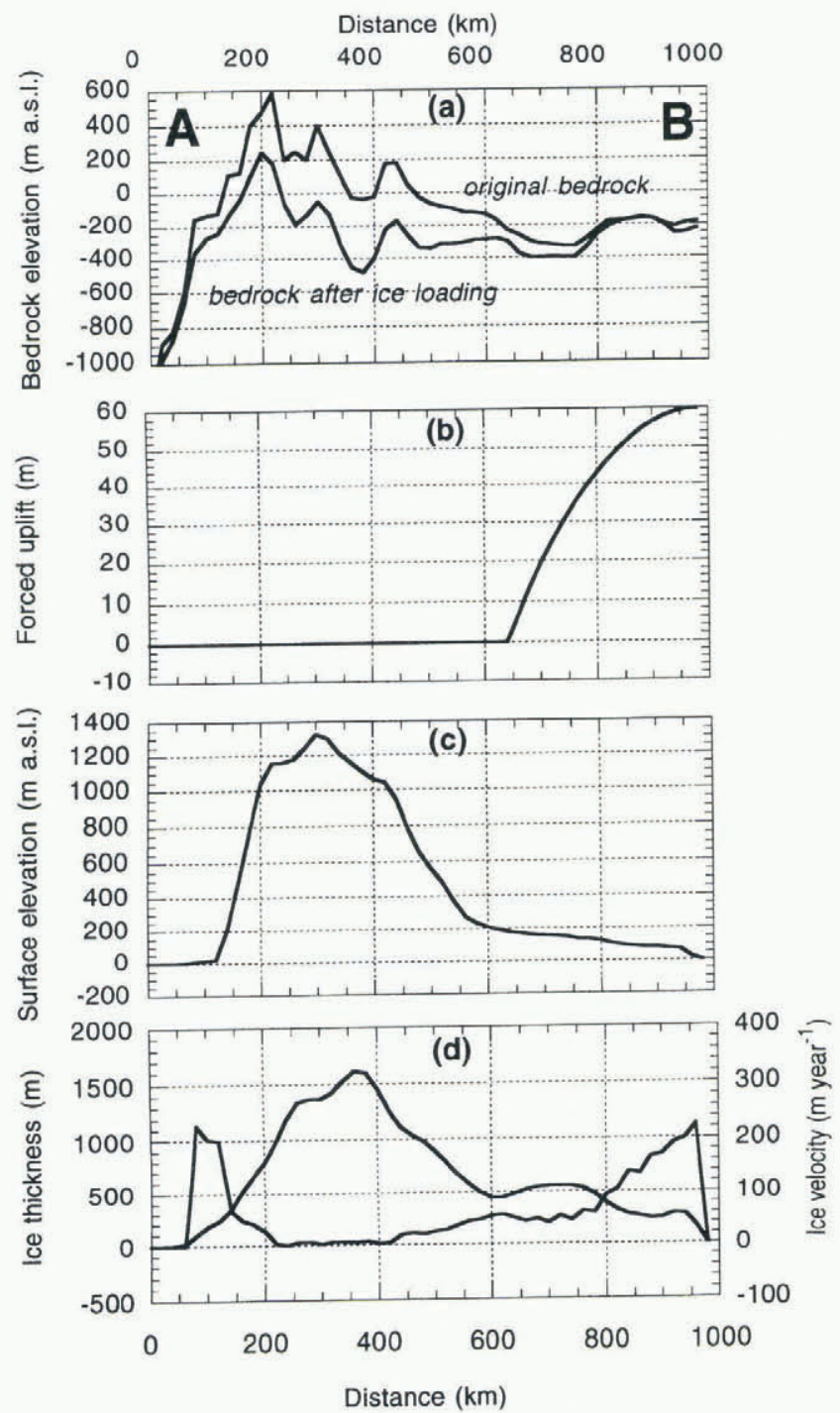

Fig. 4. One-dimensional transect model ice sheet across transect $A-B$ (Fig. 2) after $60 \mathrm{~m}$ of uplift had been applied to Sentralbanken. (a) Bedrock elevation before and after ice loading. (b) Forced uplift. (c) Ice-sheet surface elevation. (d) Ice thickness and ice velocity.

located over Sentralbanken at the southern extreme of the transect. The amplitude of the forebulge varies along the line in the form of a parabola until it reaches the ice margin, where the amplitude is $0 \mathrm{~m}$. For transect II, the Fennoscandian ice margin is located at the southern end of the line. Thus, the forebulge across this latter transect has maximum uplift located in the centre of Bjornoyrenna and zero uplift either side of the trough. The maximum uplift is varied in a sensitivity experiment to ascertain what uplift values will allow grounded ice to flow into the deeper regions of the Barents Sea. The location and geometry of the forebulges for both transects are illustrated in Figures $4 \mathrm{~b}$ and $5 \mathrm{~b}$. Uplift is imposed on the model after grounded ice has formed over the northwestern Barents Sea in a steady-state manner. The model runs for a further 5000 years after the imposition of the forebulge.

\section{ISOSTATIC UPLIFT AND ICE-SHEET GROWTH}

The glaciological model was run over both transects with bedrock uplift within the Barents Sea, as described in the isostatic model results and accounted for. The magnitude of isostatic uplift was varied in these experiments between 0 and $300 \mathrm{~m}$. The discussion on how bedrock uplift may have affected the growth of the ice sheet is divided into two sections corresponding to the two transects.

\section{Sentralbanken transect}

Grounded ice, was calculated beyond the margin of the ice sheet illustrated in Figure 2, when isostatic uplift of $60 \mathrm{~m}$ over Sentralbanken (at the southeastern end of the transect) was input to the model (Fig. 4). The ice-sheet dimensions over the north of the transect remain intact under this model run, but at the southern end between 500 and $400 \mathrm{~m}$ of ice is modelled over Sentralbanken (Fig. 4). If less than $60 \mathrm{~m}$ of uplift was imposed, the dimensions of the ice sheet remained similar to those of the initial model run where no uplift was imposed. However, if isostatic uplift in excess of $60 \mathrm{~m}$ was modelled, over $500 \mathrm{~m}$ of grounded ice formed on Sentralbanken after 5000 years of model time. If the magnitude of the forebulge exceeds $65 \mathrm{~m}$ then, taking into account $120 \mathrm{~m}$ of eustatic sea-level fall, Sentralbanken becomes subaerially exposed (as suggested by the isostatic model; Fig. 3). In this situation, grounded ice formed directly over Sentralbanken, which subsequently connected to ice in the northwestern Barents Sea, resulting in ice volumes up to $40 \%$ larger than when $60 \mathrm{~m}$ of uplift was modelled, after 5000 years of model time.

Due to the simple isostatic forebulge treatment, and to several assumptions made in this study concerning the ice masses over Fennoscandia and the Kara Sea, the subject of the timing of isostatic uplift cannot be properly addressed in this paper. However, it has been shown that $60 \mathrm{~m}$ of uplift in the central Barents Sea, caused by surrounding ice loads, provides a mechanism by which grounded ice, derived from Svalbard, may have formed over Sentralbanken.

\section{Bjørnøyrenna transect}

Imposing $60 \mathrm{~m}$ of isostatic uplift within central Bjornøyrenna did not yield results significantly different from those given in Figure 2. Sensitivity experiments concerning the magnitude of isostatic uplift indicated that over $260 \mathrm{~m}$ of uplift was required in order to allow grounded ice to flow from the north into the trough region (Fig. 5). Adjusting the timing of the isostatic uplift did not encourage ice growth beyond the ice margins detailed in Figure 2, when using uplift magnitudes less than $260 \mathrm{~m}$. Since our modelling of the isostatic forebulge indicates that $260 \mathrm{~m}$ of uplift would not have occurred in Bjornøyrenna, we conclude that this method of obtaining grounded ice in the relatively deep southern Barents Sea may be less likely than for the central Barents Sea.

\section{DISCUSSION}

If grounded ice formed over the central Barents Sea (Sentralbanken) and was connected to ice masses over the northwestern Barents Sea, Fennoscandia and the Kara 

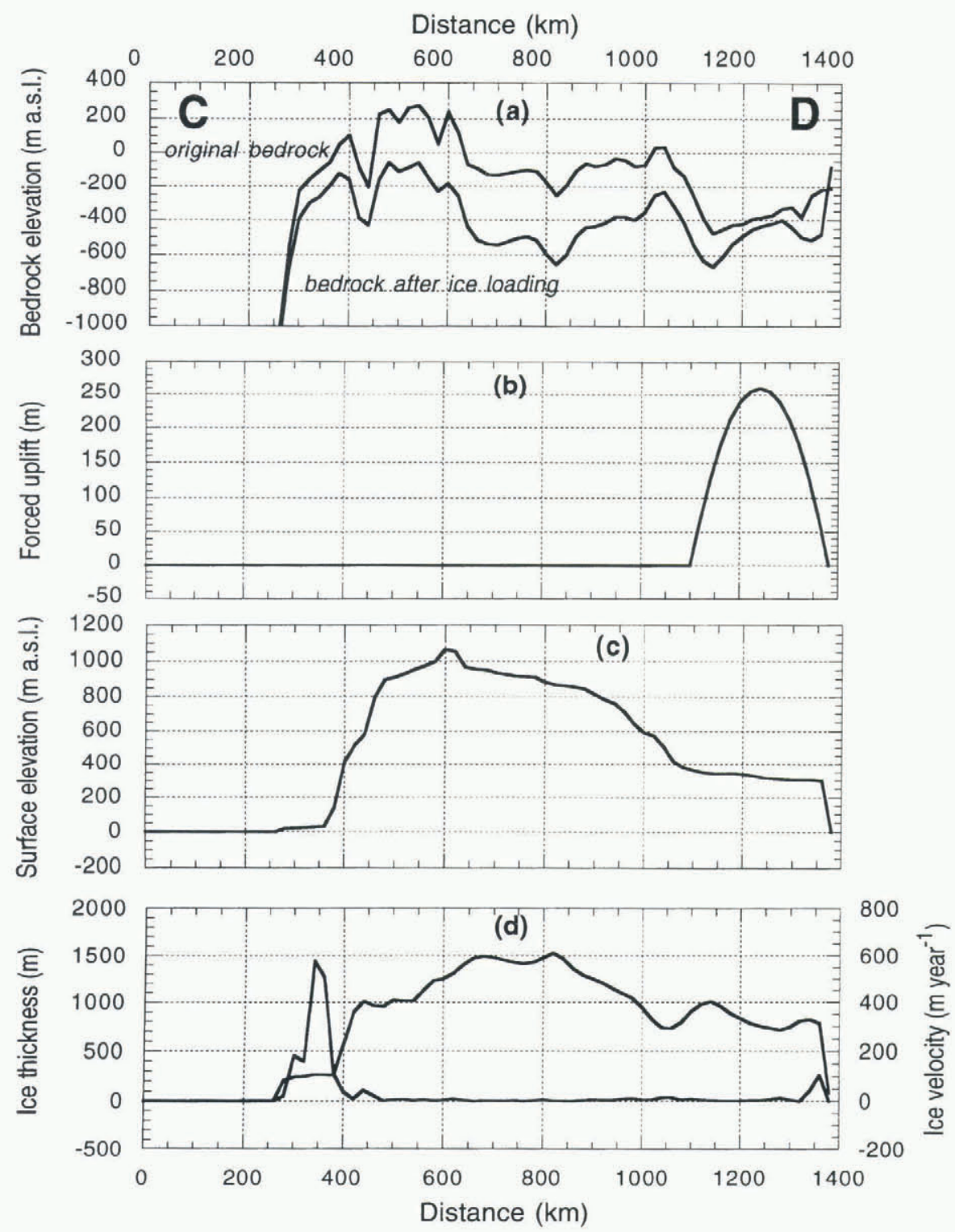

Fig. 5. One-dimensional transect model ice sheet across transect C-D (Fig. 2) after $260 \mathrm{~m}$ of uplift had been applied to Sentralbanken. (a) Bedrock elevation before and after ice loading. (b) Forced uplift. (c) Ice-sheet surface elevation. (d) Ice thickness and ice velocity.

Sea, Bjornoyrenna may have become surrounded by grounded ice to the north, east and south. Moreover, the surface gradient of the ice sheet in this area would, presumably, have been controlled by the underlying topography of the region and slope towards Bjornoyrenna. In this way, ice may have been preferentially transported into Bjornoyrenna from the grounded ice sheet, an idea proposed previously by Kvasov and Blazhchishin (1978).

Grounded-ice formation in Bjornoyrenna would, conceivably, depend largely on the rate of iceberg calving from the surrounding grounded-ice margin which, in turn, may be related to the oceanographic conditions of the eastern Norwegian Sea and the presence of relatively motionless multi-year thick sea ice within the trough.

The modelling procedure adopted in this study, which accounts for an isostatic forebulge in the central Barents Sea, assumes that ice loads on Svalbard, Novaya Zemlya and Fennoscandia occurred simultaneously. Moreover, our study also assumes that the bedrock response from this ice loading reached an equilibrium value before ice growth into the central Barents Sea took place. It should be noted that, during the Late Weichselian, ice loading peripheral to the central Barents Sea may not have occurred at the same time and, if ice was encouraged to flow from Svalbard into deeper regions of the Barents Sea by relative isostatic-forebulge-induced sea-level lowering, the bedrock may not necessarily have been in an equilibrium state. However, asynchronous ice loading and non-equilibrium bedrock adjustment within, and around, the Late Weichselian Barents Sea, may still have produced uplift of central, non-glaciated, regions of the Barents Shelf and, hence, allowed ice flow from Svalbard on to Sentralbanken. A fully two-dimensional version of a glaciological ice-sheet model coupled with an Earth model is planned, to investigate this problem.

\section{CONGLUSIONS}

Recent glaciological ice-sheet modelling has suggested that the late Weichselian ice sheet did not extend beyond 
the relatively shallow western Barents Sea (Siegert and Dowdeswell, 1995a,b). An Earth model, run with grounded-ice extent limited to the western Barents Sea, predicted that central regions of the Barents Sea would have been aerially exposed during ice-sheet build-up. Such bedrock uplift was introduced into a glaciological model across two transects, in order to investigate further which isostatic conditions would allow the formation of grounded ice in both Sentralbanken and Bjornoyrenna. Grounded ice, derived from the ice sheet over Svalbard and the northwestern Barents Sea, was calculated over Sentralbanken when $60 \mathrm{~m}$ of uplift was introduced to the model in this region (Fig. 4). Increasing magnitude of uplift to $100 \mathrm{~m}$ induced more rapid glaciation of Sentralbanken. However, grounded ice was only predicted over Bjornøyrenna after in excess of $260 \mathrm{~m}$ of uplift was imposed on the bedrock configuration within the trough (Fig. 5). We conclude that, even under sea-ice-free conditions, which permit relatively high rates of iceberg calving, Sentralbanken would have become glaciated due to the migration of grounded ice derived from Svalbard.

\section{ACKNOWLEDGEMENTS}

Professor J. A. Dowdeswell is thanked for his comments on several matters concerning the glaciation of the Barents Sea. This work is a contribution to the European Science Foundation programme on the Polar North Atlantic Margins: Late Cenozoic Evolution (PONAM).

\section{REFERENCES}

Budd, W.F., D. Jenssen and I. N. Smith. 1984. A three-dimensional time-dependent model of the West Antarctic ice sheet. Ann. Glaciol., 5, 29-36.

Cathles, L. 1975. The viscosity of the Earth's mantle. Princeton, NJ, Princeton University Press.

Denton, G.H. and T.J. Hughes. 1981. The Arctic ice sheet: an outrageous hypothesis. In Denton, G. H. and T.J. Hughes, eds. The last great ice sheets. New York, John Wiley and Sons, 437-467.

Elverhoi, A. and A. Solheim. 1983. The Barents Sea ice sheet - a sedimentological discussion. Polar Res., 1 (1), 23-42.

Elverhoi, A., W. Fjeldskaar, A. Solheim, M. Nyland-Berg and L. Russwurm. 1993. The Barents Sea ice sheet - a model of its growth and decay during the last ice maximum. Quat. Sci. Rer., 12(10), 863 873.

Fairbanks, R. G. 1989. A 17,000-year glacio-eustatic sea level record: influence of glacial melting rates on the Younger Dryas event and deep-ocean circulation. Nature, 342 (6250), 637-642.

Fjeldskaar, W. and L. Cathles. 1991. Rheology of mantle and lithosphere inferred from postglacial uplift in Fennoscandia. In Sabadini, R., K. Lambeck and E. Boschi, eds. Glacial isostacy, sea-level and mantle rheology. Dordrecht, etc., Kluwer Academic Publishers, 1 19. NATO ASI Series C: Mathematical and Physical Sciences 334.

Fortuin, J. P. F. and J. Oerlemans. 1990. Parameterization of the annual surface temperature and mass balance of Antarctica. Ann. Glaciol., 14, $78-84$.

Grosswald, M.G. 1988. An Antarctic-style ice sheet in the Northern Hemisphere; toward a new global glacial theory. Polar Geogr. Geol., $12(4), 239-267$.

Hebbeln, D., T. Dokken, E. S. Andersen, M. Hald and A. Elverhoi. 1994. Moisture supply for northern ice-sheet growth during the Last Glacial Maximum. Nature, $\mathbf{3 7 0} 6488$, 357-360.

Kvasov, D. D. and A. I. Blazhchishin. 1978. The key to sources of Pliocene and Pleistocene glaciation is at the bottom of the Barents Sea. Nature, 273 (5658), 138-140.

Laberg. J. S. and T. O. Vorren. In press a. Late Pleistocene evolution of the Bear Island Trough Mouth Fan. Global and Planetary Change, 12.

Laberg, J.S. and T. O. Vorren. In press b. Late Weichselian submarine debris flow deposits on the Bear Island Trough Mouth Fan. Mar. Geol.

Lindstrom, D. R. and D. R. MacAyeal. 1989. Scandinavian, Siberian and Arctic Ocean glaciation: effect of Holocene atmospheric $\mathrm{CO}_{2}$ variations. Science, $\mathbf{2 4 5}(4918), 628-631$.

Mahaffy, M.W. 1976. A three-dimensional numerical model of ice sheets: tests on the Barnes Ice Cap, Northwest Territories. F. Geophys. Res., 81 6), 1059-1066.

Manabe, S. and K. Bryan, Jr. 1985. $\mathrm{CO}_{2}$-induced change in a coupled ocean-atmosphere model and its paleoclimatic implications. f f. Geophys. Res., 90, 11,689-11,707.

Mangerud, J. and J. I. Svendsen. 1992. Last interglacial glacial period on Spitsbergen. Svalbard. Quat. Sci. Rev., 11 6), 633-664.

Oerlemans, J. and C.J. van der Veen, eds. 1984. Ice sheets and climate. Dordrecht, etc., D. Reidel Publishing Company,

Paterson, W.S. B. 1994. The physics of glaciers. Third edition. Oxford, etc., Elsevier Science Ltd.

Pelto, M.S. and C. R. Warren. 1991. Relationship between tidewater glacier calving velocity and water depth at the calving front. Ann. Glaciol., 15, 115118.

Pelto, M.S., S. M. Higgins, T.J. Hughes and J. L. Fastook. 1990. Modeling mass-balance changes during a glaciation cycle. Ann. Glaciol., 14, 238-241.

Robin, G. de Q. 1955. Ice movement and temperature distribution in glaciers and ice sheets. J. Glaciol., 2 18), $523-532$.

Sattem, J., D. A. R. Poole, L. Ellingsen and H. P. Sejrup. 1992. Glacial geology of outer Bjornoyrenna, southwestern Barents Sea. Mar. Geol, $103(1-3), 15-51$.

Siegert, M.J. and J.A. Dowdeswell. 1995a. Modelling ice-sheet sensitivity to Late Weichselian environments in the Svalbard-Barents Sea region. 7. Quat. Sci., 10, 33-43.

Siegert, M. J. and J. A. Dowdeswell. 1995b. Numerical modelling of the Late Weichselian Svalbard Barents Sea ice sheet. Qual. Res., $43(1)$, $1-13$.

Siegert, M.J. and J.A. Dowdeswell. In press. Topographic control on the dynamics of the Svalbard Barents Sea ice sheet. Global and Planetary Change, 12.

Vorren, T. O. and Y. Kristoflersen. 1986. Late Quaternary glaciation in the south-western Barents Sea. Boreas, 15 1), 51- 59.

Vorren, T.O., M. Hald and E. Lebesbye. 1988. Late Cenozoic environments in the Barents Sea. Paleoceanography, 3 5), 601-612. 